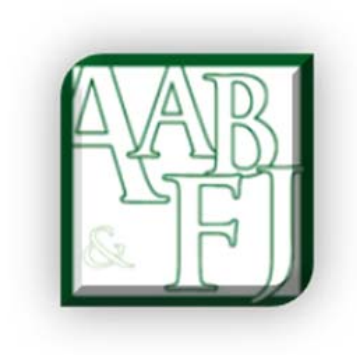

\title{
Editorial: AABFJ Volume 9, Issue 1, 2015
}

\section{Monir Mir ${ }^{1}$}

There are six excellent and diversified papers published in this edition of the Australasian Accounting, Business and Finance Journal. As highlighted below, these papers' contributions range from issues relating to accounting standard setting process to the efficient market hypothesis including a paper based on alternative accounting research methodology that explores the issues of career choices by women in a developing economy.

Yapa, Kraal and Joshi (2015) explore the socio-economic impact of the adoption of the IFRS in Singapore and Malaysia. The paper points out that the applications of some of the requirements of the IFRS are still problematic in both of these countries. However, the paper observes that the IFRS adoption process in Singapore faces fewer difficulties compared to the adoption process of Malaysia. These two countries, although they have similarities in cultural terms, have different levels of economic development. The findings of the paper support the widely held argument that the differences in the level of economic development in countries significantly affects the demand, the supply and the regulatory mechanisms of their respective accounting infrastructures.

Iddon, Hettihewa and Wright (2015) empirically investigate how capital markets value the Junior-Mining Sector (JMS). The paper contributes significantly to our knowledge concerning a sector, JMS, which has been neglected by the extant research to date. The authors have undertaken a challenging research endeavour as JMSs are unique and their valuations are not captured by the regular market mechanisms of asset valuations although they are able to raise billions of dollars from capital markets. The findings of the paper will also be useful to investors.

Hoque and Kalev (2015) introduce a new volatility measure, the intra-daily implied volatility (IDIV) for measuring price currency option and claim that IDIV is able to predict the volatility of foreign exchange pricing options better than the estimates generated by two other methods namely the implied volatility (IV) measure and the realized volatility (RV) measure. Numerous studies have been conducted to refine options pricing models since the advent of the Black and Scholes options pricing model. This paper adds another refinement towards the option pricing models and specifically investigated an under-researched area of option pricing that is, the option pricing of foreign exchanges.

Edirisuriya (2015) examines the predictive power of financial variables to predict future economic activities in the Australian context and finds that most financial variables are suitable for predicting real economic activities in Australia and hence strongly supports

\footnotetext{
${ }^{1}$ University of Canberra, Australia.
} 
continuing with the use of financial variables in predicting economic activities in Australia. Economic policy makers including politicians will benefit from the arguments that are put forward by Edirisuriya (2015) in the paper.

Developing economies need well-functioning capital/stock markets for their economic development. Although most of the developing economies have stock markets, there is a dearth of literature exploring the functioning of capital/stock markets in developing economies. Mollik and Bepari's (2015) paper move towards filling this gap through investigating the risk-return gap in the Dhaka Stock Exchange (DSE) of Bangladesh. The paper finds that, like other developed economies, DSE investors could maximise their returns if they efficiently diversified their portfolios and thereby the findings of the paper validate the efficient market hypothesis in the context of a stock market in a developing economy.

Lindawati and Smark (2015) conducted an in-depth case study about why Javanese and Indonesian women are lagging behind in choosing higher levels of public accounting careers compared to their male counterparts. Some important constraining factors have been identified by the authors in the paper which have explained why Indonesian women are not able to choose the upper echelons of public accounting careers. A careful examination of these factors should help the Indonesian policy makers in achieving their goals of increasing the participation of women at higher professional levels.

\section{References}

Edirisuriya, Piyadasa, The Predictive Power of Financial Variables: New Evidence from Australia, Australasian Accounting, Business and Finance Journal, 9(1), 2015, 5770. doi:10.14453/aabfj.v9i1.5

Hoque, Ariful and Kalev, Petko S., Pricing Currency Options with Intra-Daily Implied Volatility, Australasian Accounting, Business and Finance Journal, 9(1), 2015, 4356. doi:10.14453/aabfj.v9i1.4

Iddon, Casey; Hettihewa, Samanthala; and Wright, Christopher S., Value Relevance of Accounting and Other Variables in the Junior-Mining Sector, Australasian Accounting, Business and Finance Journal, 9(1), 2015, 25-42. doi:10.14453/aabfj.v9i1.3

Lindawati, A.S.L. and Smark, Ciorstan, Barriers to Women's Participation in the Accounting Profession in Java, Indonesia, Australasian Accounting, Business and Finance Journal, 9(1), 2015, 89-101. doi:10.14453/aabfj.v9i1.7

Mollik, Abu T. and Bepari, M. Khokan, Risk-Return Trade-off in Emerging Markets: Evidence from Dhaka Stock Exchange Bangladesh, Australasian Accounting, Business and Finance Journal, 9(1), 2015, 71-88. doi:10.14453/aabfj.v9i1.6

Yapa, Prem W.S.; Kraal, Diane; and Joshi, Mahesh, The adoption of 'International Accounting Standard (IAS) 12 Income Taxes': Convergence or divergence with local accounting standards in selected ASEAN countries?, Australasian Accounting, Business and Finance Journal, 9(1), 2015, 3-24. doi:10.14453/aabfj.v9i1.2 